\title{
Adsorption of textile dye and textile effluent using organoclay from Northeast of Brazil
}

\author{
J.V.F. L.Cavalcanti' ${ }^{1 *}$, C.C.da Fonseca ${ }^{I}$, G. M.da Silva ${ }^{I}$, I. T. Santiago ${ }^{I}$, \\ L. L. Tenório ${ }^{1}$, M.A. da Motta Sobrinho ${ }^{1}$, O.S. Baraúna ${ }^{2}$ \\ ${ }^{1}$ Universidade Federal de Pernambuco, Departamento de Engenharia Química, \\ Av. Economistas s/n, 50740-590, Recife, PE, Brazil \\ ${ }^{2}$ Instituto de Tecnologia de Pernambuco, Av. Prof. Luiz Freire 700, 50740-545, Recife, PE, Brazil
}

\begin{abstract}
The main goal of this research was to study the adsorptive capacity of an organophilic clay for the removal of textile dye Nylosan blue B113 and its further application in real textile effluent (RTE) treatment. The used clay known as Bofe was originated in the township of Boa Vista, State of Paraíba, Northeast of Brazil. Initially, the material was dried and powdered. Subsequently, the organophilic clay was synthesized by insertion of hexadecyltrimethylammonium bromide. Furthermore, the clay was characterized using the following analyses: cation exchange capacity (CEC), X-ray diffractometry (XRD), surface area analysis, and $\mathrm{pH}$ of point of zero charge $\left(\mathrm{pH}_{\mathrm{pzc}}\right)$. Then, batch adsorption systems were performed along with equilibrium/kinetic/thermodynamic studies. At last, keeping the same weight/volume ratio, a solution of real textile effluent was treated. Results showed CEC of $54.40 \mathrm{mmol} / 100 \mathrm{~g}$, lamellar expansion from 1.69 to $2.01 \mathrm{~nm}$, maximum adsorptive capacity of $50 \mathrm{mg} \cdot \mathrm{g}^{-1}$, and chemical oxygen demand (COD) removal of $74 \%$ (RTE).
\end{abstract}

Keywords: adsorption, montmorillonite clay, organoclay, textile dye, textile effluent.

\section{INTRODUCTION}

Textile industries hold an important position in the global industrial scenario due to their contribution to the basic human needs and world economy. However, these industries are major consumers of water, dyes, and other toxic chemicals [1]. Over 100000 types of commercial dyes are used in industries [2]. Currently, some of the most relevant industries such as textile, printing, and dyestuff require large amounts of organic dyes in their processes due to their great market demand and inefficient dyeing processes. Consequently, water pollution caused by dye has increased over the past decade [3, 4]. Most organic dyes contain toxic and carcinogenic compounds that could lead to negative effects on the environment and are often discharged with wastewater into hydric bodies, thus contaminating the exposed aquatic biota and consequently the whole natural ecosystem, which could result in a decrease in the reparation capacity of streams and irreversible damage. Also, they are highly stable and soluble in water and many are difficult to be downgraded for containing complex aromatic molecular structures like azo dyes [5, 6]. For these reasons, dye wastewater is regarded as one of the main sources of water pollution, being its decontamination a crucial step prior to their release and a challenging issue to nowadays' environmental safety $[7,8]$. Wastewater treatment technologies renovate ceaselessly in search of more effective, flexible processes and abundant natural materials for the

*jorge.cavalc@ufpe.br

Ohttps://orcid.org/0000-0001-8006-1556 treatment of industrial effluents and contaminated sites [9]. There are several techniques available for dye removal from wastewater; advanced oxidation, biodegradation, and adsorption are widely known examples, being the latter one of the most researched methods presently for its low cost, ease of operation, and efficiency [10], and natural clay as one of the mainly used and researched adsorbents for its several properties, types, abundance and low price [11]. Also, there is the possibility of cations exchange to prepare an organophilic material.

Natural clays can be combined or modified to increase their efficiency in the adsorption capacity of organic pollutants or to generate several different materials and properties. Most contain phyllosilicates and present large surface area and exchangeable ions, being differentiated by their structure, mineralogy, and ionic substitutions, such as ammonium quaternary cations $[12,13]$. Montmorillonite clay is one of the most regarded clays among researchers. It presents high sorptive capacity due to its long layers, high surface area, and exchangeable ions, thus largely expanding interlayer space for water and ion penetration [14]. This type of clay presents a 2:1 layer silicate consisting of one sheet of octahedral alumina between two tetrahedral silica sheets, thus being part of the smectite group. Clay modification has been extensively studied for transforming natural clay into new materials with new applications, being organophilization a noticeable example $[15,16]$. Organophilization transforms hydrophilic clay into organophilic clay (organoclay) by transforming its hydrophilic interlayer space into hydrophobic through an ion exchange reaction with a surfactant, such as the hexadecyltrimethylammonium bromide salt (HDTMA- 
$\mathrm{Br})$, besides other quaternary ammonium salts $[17,18]$.

Adsorptive processes between organoclay and textile dyes could fit the experimental data according to the Langmuir isotherm (LI) and the Langmuir-Freundlich isotherm (LFI). LI assumes the existence of adsorption sites, all energetically equivalent, where only one molecule is adsorbed per site, without any interaction with molecules adsorbed on the neighboring sites. However, the LFI considers the non-uniformity of the surface adsorption sites [19]. The Langmuir isotherm is shown in Eq. A, and the Langmuir-Freundlich isotherm is shown in Eq. $\mathrm{B}$, where $\mathrm{C}_{\mathrm{eq}}$ is the concentration of adsorbate in the liquid phase $\left(\mathrm{mg} \cdot \mathrm{L}^{-1}\right)$, $\mathrm{q}_{\mathrm{eq}}$ is the concentration of adsorbate in the solid phase (mg. $\mathrm{g}^{-1}$ ), $\mathrm{q}^{\max }$ is the maximum adsorption capacity $\left(\mathrm{mg} \cdot \mathrm{g}^{-1}\right), \mathrm{K}$ is the affinity constant of adsorption, and $1 / \mathrm{n}$ is the heterogeneity index:

$$
\begin{gathered}
\frac{q_{e q}}{q^{\max }}=\frac{K \cdot C_{e q}}{1+K \cdot C_{e q}} \\
\frac{q_{e q}}{q^{\max }}=\frac{K \cdot C_{e q}^{1 / n}}{1+K \cdot C_{e q}^{1 / n}}
\end{gathered}
$$

Some adsorptive kinetic models have been used in different researches employing the Lagergren models, also called pseudo-first order model and pseudo-second order model, represented by Eqs. C and D [19, 20], respectively, where $\mathrm{k}_{1}\left(\mathrm{~min}^{-1}\right)$ and $\mathrm{k}_{2}\left(\mathrm{~g} \cdot \mathrm{mg}^{-1} \cdot \mathrm{min}^{-1}\right)$ are the adsorptive kinetic constants:

$$
\begin{aligned}
& \frac{d q_{t}}{d t}=k_{1}\left(q_{e q}-q_{t}\right) \rightarrow q_{t}=q_{e q}\left(1-e^{\left(-k_{1} t\right)}\right) \\
& \frac{d q_{t}}{d}=k_{2}\left(q_{e q}-q_{t}\right)^{2} \rightarrow q_{t}=\frac{q_{e q} t}{\frac{1}{q_{e q} k_{2}}+t}
\end{aligned}
$$

The values of $\mathrm{C}_{\mathrm{eq}}$ ( or $\mathrm{C}_{\mathrm{t}}$ ) can be obtained experimentally, and the values of $\mathrm{q}_{\mathrm{eq}}$ (or $\left.\mathrm{q}_{\mathrm{t}}\right)$ can be calculated according to the material balance represented in Eq. E, where V represents the volume of the solution ( $\mathrm{L}$ ) and $\mathrm{m}$ denotes the weight of the adsorbent $(\mathrm{g})$ :

$$
\mathrm{q}_{\mathrm{t} / \mathrm{eq}}=\left(\mathrm{C}_{\text {initial }}-\mathrm{C}_{\mathrm{t} / \mathrm{eq}}\right) \frac{\mathrm{v}}{\mathrm{m}}
$$

Finally, a comparative table presenting adsorptive studies, including different clay types and different textile dyes, is shown in Table I. Some studies presented good coating, between $5 \%$ and $10 \%(\mathrm{w} / \mathrm{w})$, and others presented excellent coating, superior to $20 \%(\mathrm{w} / \mathrm{w})$. In this table, it is possible to find research using HDTMA that produced material with $\mathrm{q}^{\max }>200 \mathrm{mg} \cdot \mathrm{g}^{-1}$. However, it is important to notice that the maximum adsorption capacity depends on the material and the compound (textile dye), and on all the surrounding physicalchemical conditions.

Based on the above considerations, this work aims to simulate the dye removal treatment for synthetic solutions, and real effluent of a textile company, being the latter collected in Caruaru (PE)-Brazil, through an adsorption process using HDTMA-modified local natural clay, collected in Boa Vista (PB)-Brazil.

\section{MATERIALS AND METHODS}

Adsorbent material - preparation and characterization: initially, a Bofe clay sample, from the township of Boa Vista (Paraíba, Brazil), was dried at $105^{\circ} \mathrm{C}$ in a furnace for $24 \mathrm{~h}$ and powdered to 100 mesh $(0.149 \mathrm{~mm})$. Then, two different types of organophilic clay were produced by the exchange of poly-cations, on the mineral surface of montmorillonite, for the hexadecyl-trimethyl-ammonium (HDTMA) cations from hexadecyl-trimethyl-ammonium bromide (HDTMA-Br, Cetremide PNOQUIMIOS, 98.0\%

Table I - Data related to some adsorptive studies from organoclays and textile dyes.

\begin{tabular}{cccc}
\hline Organoclay type & Textile dye & $\begin{array}{c}\text { Maximum adsorption } \\
\text { capacity }\left(\mathrm{mg} \cdot \mathrm{g}^{-1}\right)\end{array}$ & Ref. \\
\hline Organo-palygorskite-Fe ${ }_{3} \mathrm{O}_{4}$ nanomaterial & Indigo carmine & 120 & {$[4]$} \\
Montmorillonite treated with gemini surfactants & Methyl orange & 70 & {$[6]$} \\
Montmorillonite treated with HDTMA salt & Methyl orange & 250 & 211 \\
Bemazol blue RN & Methylene blue & 127 & {$[21]$} \\
Bentonite treated with HDTMA-Cl salt & Crystal violet & 148 & {$[22]$} \\
Smectite-rich clayey rock sulfuric-acid-activated & Rhodamine B & 18 & {$[23]$} \\
Montmorillonite treated with tetra-n- & Indanthrene blue RS & 33 & This \\
butylammonium bromide & Toluidine blue & 39 & research \\
\hline
\end{tabular}


purity). The concentrations of HTDMA cations were 1.5 times (organoclay A) and 2.0 times (organoclay B) of the natural clay's cation exchange capacity (CEC) [19]. In this experiment, $10 \mathrm{~g}$ of natural clay was dispersed into $500 \mathrm{~mL}$ of an HDTMA solution containing $8.16 \mathrm{mmol}$ (organoclay A) and $10.88 \mathrm{mmol}$ (organoclay B) at room temperature $\left(28 \pm 1{ }^{\circ} \mathrm{C}\right), 6 \mathrm{~h}$ contact time, and $210 \mathrm{rpm}$ orbital agitation. Finally, in the same order, the samples of organoclay were filtered, dried at $60{ }^{\circ} \mathrm{C}$ in a furnace for 48 $\mathrm{h}$, and powdered to 100 mesh. The samples of Bofe clay (natural and organophilic A) were characterized by X-ray diffraction (XRD, Ultima, Rigaku); surface area analysis by nitrogen adsorption/desorption isotherms (2010 ASAP, Micromeritics; multipoint BET method for surface area determination); and $\mathrm{pH}$ of point of zero charge using solutions of initial $\mathrm{pH} 2-12$, by $\mathrm{HCl}$ or $\mathrm{NaOH}$ additions (50 $\mathrm{mL}$ and $0.1 \mathrm{~g}$ of adsorbent material).

Textile dye and real effluent - analytical methods: the textile dye used was the Nylosan blue B113 (NB, Clariant, $99 \%$ purity), an acid/anionic dye. The analytical curve of NB was carried out by five solutions of NB 20-100 mg.. $\mathrm{L}^{-1}$ using the Lambert-Beer equation, a correlation between the absorbances of the solutions and the concentrations of textile dye. The absorbances were analyzed at $600 \mathrm{~nm}$, using a spectrophotometer (10 UV/Vis, Genesys). The real textile effluent (RTE) was characterized by: chemical oxygen demand (COD), according to the standard methods of water and wastewater (APHA $5220 \mathrm{C}$ ); color, utilizing a colorimeter (NOVA60, Spectroquant); and turbidity, utilizing a turbidimeter (Q279P, Quimis). Real effluents contain several contaminants in their mixture. Therefore, the chemical oxygen demand (COD) analysis was performed to assess this global parameter. COD represents the amount of oxygen that must be consumed to stabilize the effluent. To perform this analysis, the effluent was oxidized by dichromate ions, and the excess was titrated by ferrous ammonium sulfate. Color and turbidity were analyzed in calibrated equipment and assisted in the effluent characterization. These analyses represented the color intensity and the presence of particulate material in the effluent, respectively. Potassium dichromate and ferrous ammonium sulfate (F. Maia, $99.0 \%$ and $98.5 \%$ purity, respectively) were used.

Adsorptive studies - equilibrium, kinetic, and thermodynamic (textile dye) and COD removal (real effluent): the equilibrium study was performed utilizing 7 (in duplicate) isolated NB solutions of $50 \mathrm{~mL}$, with initial dye solution concentrations of $20,40,60,80,100,120$ and $160 \mathrm{mg} . \mathrm{L}^{-1}, 0.1 \mathrm{~g}$ of adsorbent (using the natural clay and the organoclays A and $\mathrm{B}$ ), natural $\mathrm{pH}$ (approximately 5.5), at room temperature $\left(28 \pm 1{ }^{\circ} \mathrm{C}\right)$, in Erlenmeyer flasks of $125 \mathrm{~mL}$ (covered with plastic film). The suspension was shaken for $6 \mathrm{~h}$ at $210 \mathrm{rpm}$ and then the samples were filtered. Three curves of equilibrium adsorption capacity $\left(\mathrm{q}_{\mathrm{eq}}\right)$ versus equilibrium concentration $\left(\mathrm{C}_{\mathrm{eq}}\right)$ were fitted. The kinetic study was performed utilizing 8 (in duplicate) isolated $\mathrm{NB}$ solutions of $50 \mathrm{~mL}$, with an initial dye solution concentration of $100 \mathrm{mg} \cdot \mathrm{L}^{-1}, 0.1 \mathrm{~g}$ of adsorbent (using the natural clay and the organoclay A), natural $\mathrm{pH}$ (approximately 5.5$)$, at room temperature $\left(28 \pm 1{ }^{\circ} \mathrm{C}\right)$, in Erlenmeyer flasks of $125 \mathrm{~mL}$ (covered with plastic film). The suspension was shaken for $6 \mathrm{~h}$ at $210 \mathrm{rpm}$ and then the samples were filtered at 1, 5, 10,30,60,120,240, and $360 \mathrm{~min}$. Two curves of adsorption capacity (q) versus time (t) were fitted. The thermodynamic study was performed utilizing 7 (in duplicate) isolated NB solutions of $50 \mathrm{~mL}$, with initial dye solution concentrations of $20,40,60,80$, 100,120 , and $160 \mathrm{mg} . \mathrm{L}^{-1}, 0.1 \mathrm{~g}$ of adsorbent (organoclay A), natural $\mathrm{pH}$ (approximately 5.5), at room temperature $\left(28 \pm 1{ }^{\circ} \mathrm{C}\right)$ and controlled temperature $\left(40.0 \pm 0.1^{\circ} \mathrm{C}\right)$, in Erlenmeyer flasks of $125 \mathrm{~mL}$ (covered with plastic film). The suspension was shaken for $6 \mathrm{~h}$ at $210 \mathrm{rpm}$ and, then, the samples were filtered. Two curves of equilibrium adsorption capacity $\left(\mathrm{q}_{\mathrm{eq}}\right)$ versus equilibrium concentration $\left(\mathrm{C}_{\mathrm{eq}}\right)$ were fitted. Finally, the adsorptive study of the RTE was carried out with a real sample of textile effluent, comparing the initial and final COD, color, and turbidity. The experiment was performed in duplicate, at room temperature $\left(28 \pm 1{ }^{\circ} \mathrm{C}\right)$, natural $\mathrm{pH}$ (approximately 4.5 ), in Erlenmeyer flasks of $125 \mathrm{~mL}$ (covered with plastic film), with $50 \mathrm{~mL}$ of solution and $0.1 \mathrm{~g}$ of organoclay A. The suspension was shaken for $6 \mathrm{~h}$ at $210 \mathrm{rpm}$ and then the supernatants were collected at 1, 5, 10, 30, 60, 120, 240, and $360 \mathrm{~min}$. A curve of COD versus time (t) was fitted. Then, a comparative study of initial/final COD, color, and turbidity was performed.

\section{RESULTS AND DISCUSSION}

Adsorbent material - characterization: the cation exchange capacity (CEC) represents the sum of all cations present in the interlayer regions. The results for the Bofe natural clay were $54.40 \mathrm{mmol} / 100 \mathrm{~g}$ (Table II). The order of magnitude of the CEC was near to other researches, which presented CEC of 52 and $64 \mathrm{mmol} / 100 \mathrm{~g}$ [2, 21]. The X-ray diffraction patterns of Bofe clay and organoclay were recorded (Fig. 1). Utilizing a 20/Copper table, the interlayer distances were determined. The results were $1.69 \mathrm{~nm}$ to natural clay, $2.01 \mathrm{~nm}$ to organoclay A, and 2.03 $\mathrm{nm}$ to organoclay B. Comparing the organoclays A and B, the small increase of the peak intensity could represent a little greater number of interlayers, however, this situation most probably represented operational differences in the analysis, in different moments and different intensity calibration. The expansion of the interlayer indicated an effective exchange of the poly-cations to quaternary ammonium cations. These results can be compared to other researches that presented increases from 1.41 to $1.86 \mathrm{~nm}$, and 1.50 to $2.06 \mathrm{~nm}[2,9]$.

Table II - CEC (mmol/100g) of the Bofe natural clay.

\begin{tabular}{cccccccc}
\hline $\mathrm{Ca}^{2+}$ & $\mathrm{Mg}^{2+}$ & $\mathrm{Na}^{+}$ & $\mathrm{K}^{+}$ & $\mathrm{Al}^{3+}$ & $\mathrm{H}_{3} \mathrm{O}^{+}$ & $\mathrm{pH}$ & $\mathrm{CEC}$ \\
\hline 10.30 & 34.80 & 6.60 & 0.30 & $<0.01$ & 2.39 & 5.60 & 54.40 \\
\hline
\end{tabular}




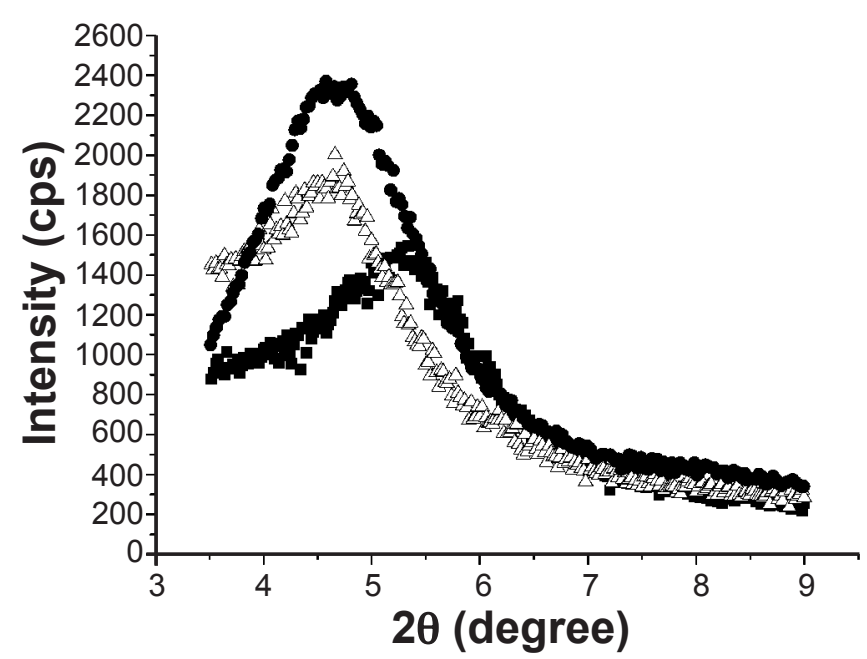

Figure 1: X-ray diffraction patterns of Bofe clay: natural clay ( $\mathbf{})$, organoclay A $(\Delta)$, and organoclay B $(\bullet)$.

The surface area of the natural clay, organoclay A and organoclay B, obtained from nitrogen adsorption/desorption isotherms (Fig. 2) using multipoint BET, was 106.9, 32.0, and $31.5 \mathrm{~m}^{2} \cdot \mathrm{g}^{-1}$, respectively. The IUPAC classification of the three samples was type IV. Materials with this classification present a hysteresis cycle, associated with capillary condensation into the mesoporous. The average pore radius was $38.4,19.9$, and $19.3 \AA$ to natural clay, organoclay $\mathrm{A}$ and organoclay $\mathrm{B}$, respectively. The results indicated that the HDTMA cations entered the interlayers of natural clay, overlapped its surface, and blocked the channel between the layers, reducing the surface area [2, 9]. The $\mathrm{pH}$ of the point of zero charge was $6.18,7.03$, and 7.55 to natural clay and organoclays $\mathrm{A}$ and $\mathrm{B}$, respectively. The $\mathrm{pH}$ of point of zero charge $\left(\mathrm{pH}_{\mathrm{pzc}}\right)$ indicated that the surface of the material adsorbent was positive in systems with $\mathrm{pH}$ 's below $6.18,7.03$, and 7.55 to natural clay and organoclays $\mathrm{A}$ and $\mathrm{B}$, respectively. The insertion of quaternary ammonium cations provoked alkalization on the clay surface. This result can indicate an electrostatic approximation between anionic dye and adsorbent material at $\mathrm{pH}$ below $\mathrm{pH}_{\mathrm{pzc}}$, e.g. $\mathrm{pH} \cong 5.5$

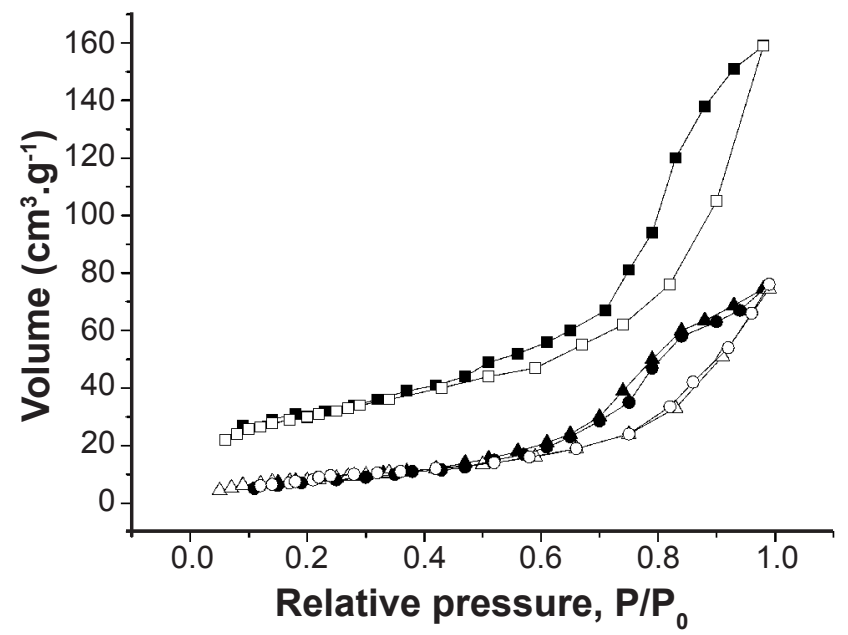

Figure 2: Nitrogen adsorption/desorption isotherms of natural clay $(\bullet / \square)$, organoclay A $(\mathbf{\Delta} / \triangle)$, and organoclay B $(\bullet / \circ)$.

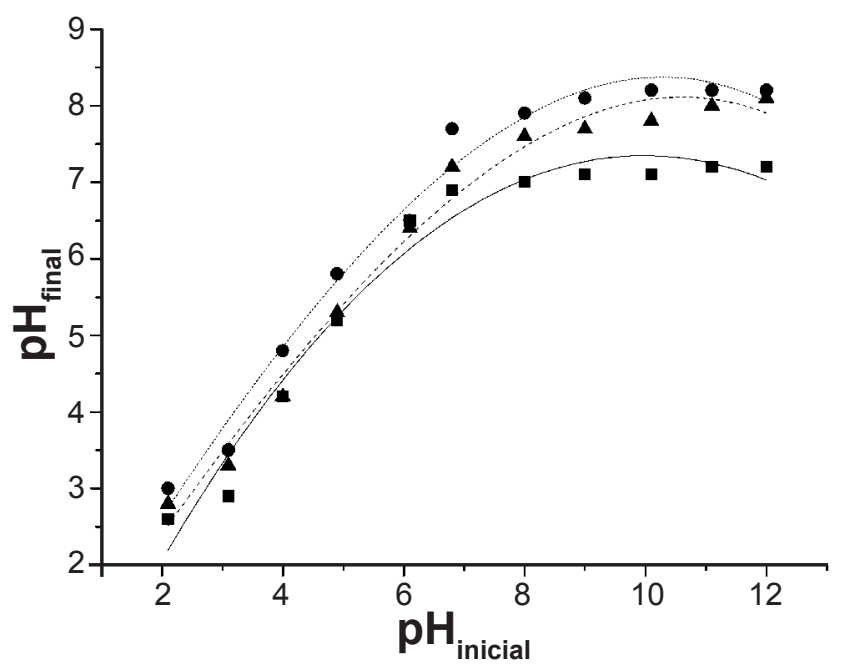

Figure 3: $\mathrm{pH}_{\mathrm{pzc}}$ of natural clay ( $\left.\mathbf{\bullet}\right)$, organoclay A ( $\left.\mathbf{(}\right)$, and organoclay $\mathrm{B}(\bullet): \mathrm{y}=0.0005 \mathrm{x}^{3}-0.0949 \mathrm{x}^{2}+1.7339 \mathrm{x}-1.0333, \mathrm{R}^{2}=0.959$ (solid line, $\left.\mathrm{y}=\mathrm{x}=\mathrm{pH}_{\mathrm{pzc}}=6.18\right) ; \mathrm{y}=-0.0027 \mathrm{x}^{3}-0.0078 \mathrm{x}^{2}+1.1717 \mathrm{x}+0.1177$, $\mathrm{R}^{2}=0.978 \quad$ (dashed line, $\mathrm{y}=\mathrm{x}=\mathrm{pH}_{\mathrm{pzc}}=7.03$ ); $\mathrm{y}=-0.0029 \mathrm{x}^{3}-$ $0.0228 \mathrm{x}^{2}+1.3271 \mathrm{x}+0.0809, \quad \mathrm{R}^{2}=0.985^{\mathrm{pzc}}$ (short dashed line, $\left.\mathrm{y}=\mathrm{x}=\mathrm{pH}_{\mathrm{pzc}}=7.55\right)$.

(dye solutions of this research) $<6.18$ or 7.03 or 7.55 . To determinate the $\mathrm{pH}_{\mathrm{pzc}}$, cubic polynomials were fitted, when $\mathrm{pH}_{\text {final }}=\mathrm{pH}_{\text {initial }}=\mathrm{pH}_{\mathrm{pzc}}$ (Fig. 3).

Textile dye and real effluent: an analytical curve was fitted using the Lambert-Beer equation. The correlation was $\mathrm{A}=0.017 \mathrm{C}+0.029, \mathrm{R}^{2}=0.993$. The limit of detection (LOD) was $0.40 \mathrm{mg} . \mathrm{L}^{-1}$ and the limit of quantification (LOQ) was $1.22 \mathrm{mg} . \mathrm{L}^{-1}$. In addition, to real textile effluent, the results of initial COD, color, and turbidity were $929.4 \mathrm{mgO}_{2} \cdot \mathrm{L}^{-1}$, 1.044 Hazen, and 516 NTU, respectively. These results were according to an average composition of textile effluent [24].

Adsorptive studies: initially, the equilibrium experimental data were plotted to the adsorption isotherm of textile dye onto organoclays A and B (Fig. 4a). It was not observed a significant variation between the equilibrium adsorption capacities $\left(\mathrm{q}_{\mathrm{eq}}\right)$ of organoclay A compared with organoclay B. This situation was observed in the adsorptive studies and is shown in material characterization. Probably, during the preparation of organo-materials, the excess of HDTMA was lixiviated. Consequently, due to minor use of the quaternary ammonium salt, the organoclay A was chosen to continue the research. Subsequently, the equilibrium experimental data were analyzed and fitted to two adsorption isotherms. Fig. 4b shows the results regarding the non-linear fittings to Langmuir and Langmuir-Freundlich equations of natural clay and organoclay A. Table III presents the data for the nonlinear adjustments to the proposed models, which show that equilibrium data was satisfactorily adjusted to LangmuirFreundlich isotherm, indicating heterogeneous regions on the adsorbent surface and interactions with variable energy [25]. The superior coefficient of determination $\left(\mathrm{R}^{2}\right)$ and lesser residual sum of squares (rss) confirmed this physicalchemical behavior. Considering the equilibrium adsorption study on natural clay and organoclay A (Fig. 4b), different 

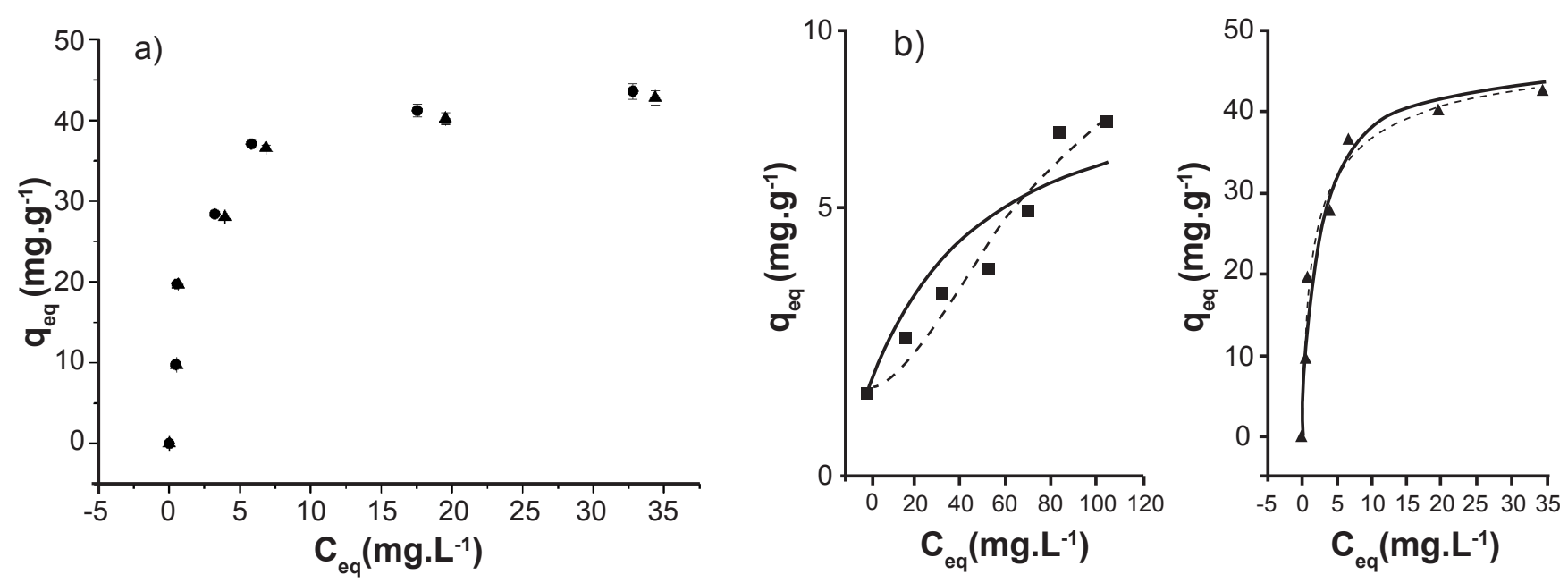

Figure 4: Isotherms for the adsorption of textile dye ( $\left.\mathrm{pH} \cong 5.5, \mathrm{~T} \cong 28 \pm 1^{\circ} \mathrm{C}\right)$ onto: a) organoclay $\mathrm{A}(\mathbf{\Delta})$ and organoclay $\mathrm{B}$; and b) natural clay $(\mathbf{})$ and organoclay A ( $\mathbf{\Delta}$ ) with fits of Langmuir (solid line) and Langmuir-Freundlich (dashed line) models.

Table III - Equilibrium data results using the Langmuir and Langmuir-Freundlich isotherms.

\begin{tabular}{|c|c|c|c|c|}
\hline \multirow[b]{2}{*}{ Parameter } & \multicolumn{2}{|c|}{ Natural clay } & \multicolumn{2}{|c|}{ Organoclay A } \\
\hline & $\begin{array}{l}\text { Langmuir } \\
\text { isotherm }\end{array}$ & $\begin{array}{l}\text { Langmuir-Freundlich } \\
\text { isotherm }\end{array}$ & $\begin{array}{l}\text { Langmuir } \\
\text { isotherm }\end{array}$ & $\begin{array}{l}\text { Langmuir-Freundlich } \\
\text { isotherm }\end{array}$ \\
\hline $\mathrm{q}^{\max }\left(\mathrm{mg} \cdot \mathrm{g}^{-1}\right)$ & $9.4 \pm 0.8$ & $11.2 \pm 2.1$ & $46.3 \pm 2.3$ & $49.5 \pm 3.8$ \\
\hline K & $0.020 \pm 0.006$ & $(3.4 \pm 1.3) \times 10^{-4}$ & $0.49 \pm 0.15$ & $0.60 \pm 0.15$ \\
\hline $1 / \mathrm{n}$ & - & $0.55 \pm 0.14$ & - & $1.49 \pm 0.29$ \\
\hline $\mathrm{R}^{2}$ & 0.858 & 0.958 & 0.943 & 0.964 \\
\hline rss & 6.655 & 1.618 & 89.237 & 47.724 \\
\hline
\end{tabular}

initial concentrations of dye were adsorbed in the same weight/volume ratio for both materials. It was observed that organoclay A adsorbed a much more expressive quantity than natural clay, highlighting its adsorptive properties after the change provoked by ammonium quaternary salt. The relation between the equilibrium adsorption capacity $\left(\mathrm{q}_{\mathrm{eq}}\right)$ and the dye concentration in liquid media at equilibrium $\left(\mathrm{C}_{\mathrm{eq}}\right)$, for this research, was evaluated by the Langmuir and Langmuir-Freundlich models (Eqs. A and B, respectively). It is emphasized that the maximum adsorption capacity increased from 11.2 to $49.5 \mathrm{mg} . \mathrm{g}^{1}$ between natural clay and organoclay A, as shown in Table III.

The kinetic experimental data were analyzed and fitted to two adsorption models. Fig. 5 shows the results regarding the non-linear fittings to pseudo-first order (PFO) and pseudo-second order (PSO) models for the natural clay and organoclay A. For natural clay, according to Fig. 5 and Table IV, the PFO and PSO models superposed, possibly indicating the only adsorption around the surface in a reversible process. However, for organoclay, kinetic data were satisfactorily adjusted to pseudo-second order model. The order of chemical reactions in homogeneous processes is proportional to the maximum initial rate of the chemical reaction and the initial concentration of the reagent. In adsorptive processes, the maximum rate of adsorption is proportional to the driving force $\left(\mathrm{q}_{\mathrm{eq}}-\mathrm{q}\right)^{\alpha}$ raised to the order $(\alpha)$. In second order processes, there are several mechanisms that can happen, e.g. low surface resistance, ion exchange, particles diffusion in the pores of the adsorbent, among others $[12,25,26]$.

In order to deepen the adsorption study and better understand the dye-organoclay adsorptive mechanism, a thermodynamic study was performed, according to the Van't Hoff equation:

$$
\ln \mathrm{K}=\frac{\Delta \mathrm{S}^{\mathrm{o}}}{\mathrm{R}}-\frac{\Delta \mathrm{H}^{\mathrm{o}}}{\mathrm{R}}\left(\frac{1}{\mathrm{~T}}\right)
$$

where $\mathrm{T}$ is the temperature at which the adsorption takes place (kelvin), $\mathrm{K}$ is the equilibrium constant under a given temperature, $\Delta S^{\circ}$ is the variation of entropy $\left(\mathrm{J} \cdot \mathrm{mol}^{-1} \cdot \mathrm{K}^{-1}\right)$, $\Delta H^{\circ}$ is the variation of enthalpy $\left(\mathrm{J} \cdot \mathrm{mol}^{-1}\right)$, and $\Delta \mathrm{G}^{\circ}$ is the variation of Gibbs energy $\left(\mathrm{J} \cdot \mathrm{mol}^{-1}\right)$. Fig. 6 shows the results regarding the non-linear fittings to the Langmuir-Freundlich equation for organoclay $\mathrm{A}$ at 28 and $40{ }^{\circ} \mathrm{C}$. Table $\mathrm{V}$ presents the data for the non-linear adjustments to the proposed model and the thermodynamic analysis. The increase in the temperature caused the displacement of equilibrium in the adsorption direction. The thermodynamic results indicated 
Table IV - Kinetic data results using the pseudo-first order (PFO) and pseudo-second order (PSO) models.

\begin{tabular}{ccccc}
\hline Parameter & $\begin{array}{c}\text { Natural clay } \\
\text { PFO }\end{array}$ & $\begin{array}{c}\text { Natural clay } \\
\text { PSO }\end{array}$ & $\begin{array}{c}\text { Organoclay A } \\
\text { PFO }\end{array}$ & $\begin{array}{c}\text { Organoclay A } \\
\text { PSO }\end{array}$ \\
\hline $\mathrm{q}_{\mathrm{eq}}\left(\mathrm{mg} \cdot \mathrm{g}^{-1}\right)$ & $7.7 \pm 0.3$ & $8.3 \pm 0.4$ & $37.2 \pm 2.5$ & $38.7 \pm 2.2$ \\
$\mathrm{k}_{1}\left(\mathrm{~min}^{-1}\right)$ & $0.119 \pm 0.023$ & - & $0.146 \pm 0.045$ & - \\
$\mathrm{k}_{2}\left(\mathrm{~g}_{\mathrm{mg}} \mathrm{mg}^{-1} \cdot \mathrm{min}^{-1}\right)$ & - & $0.019 \pm 0.007$ & - & $0.008 \pm 0.003$ \\
$\mathrm{R}^{2}$ & 0.956 & 0.947 & 0.841 & 0.906 \\
$\mathrm{rss}$ & 3.381 & 4.005 & 203.626 & 119.180 \\
\hline
\end{tabular}

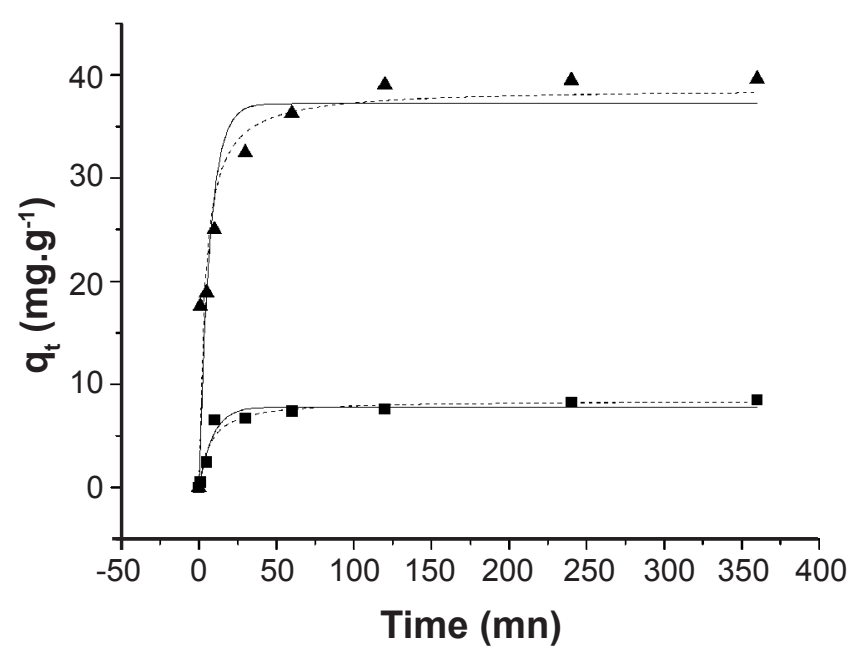

Figure 5: Comparison of kinetic models for the adsorption of textile dye onto natural clay ( $\mathbf{-}$ ) and organoclay A ( $\mathbf{(})$, by PFO (solid line) and PSO (dashed line) models $\left(\mathrm{C}_{0}=100 \mathrm{mg} \cdot \mathrm{L}^{-1}, \mathrm{pH} \cong 5.5, \mathrm{~T} \cong 28 \pm 1^{\circ} \mathrm{C}\right)$.

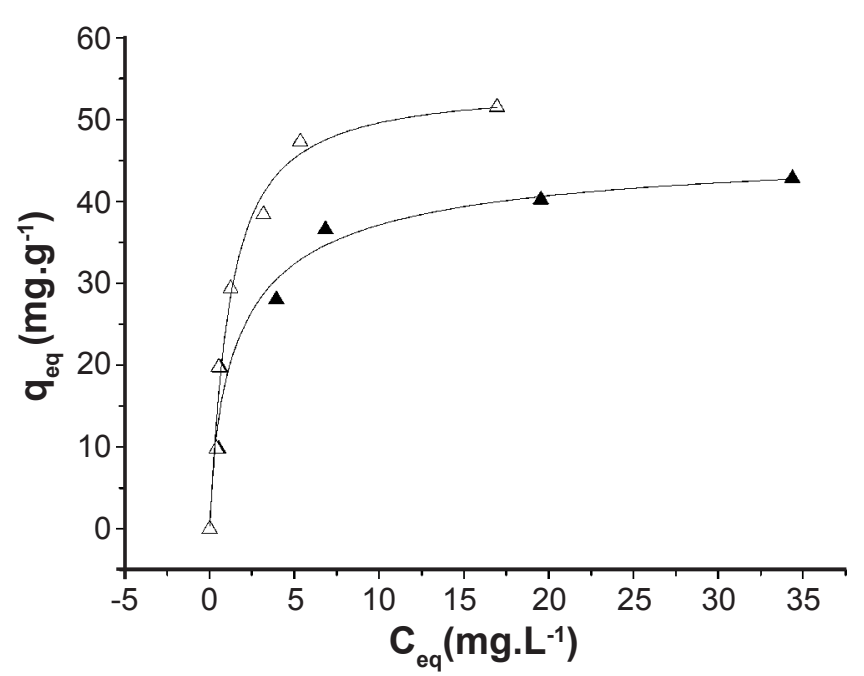

Figure 6: Comparison of Langmuir-Freundlich isotherm for the adsorption of textile dye onto organoclay A at $28^{\circ} \mathrm{C}(\mathbf{\Delta})$ and $40^{\circ} \mathrm{C}$ $(\Delta)(\mathrm{pH} \cong 5.5)$.

that the interaction of the dye molecule with HDTMA-clay was endothermic by physisorption (20-40 kJ.mol ${ }^{-1}$ ), and the positive $\Delta S^{\circ}$ suggested increasing in disorder at the solidliquid interface during the spontaneous $\left(\Delta \mathrm{G}^{\circ}<0\right)$ adsorption
Table V - Equilibrium data results using the LangmuirFreundlich isotherm at 28 and $40{ }^{\circ} \mathrm{C}$ for organoclay A.

\begin{tabular}{ccc}
\hline Parameter & $28^{\circ} \mathrm{C}$ & $40^{\circ} \mathrm{C}$ \\
\hline $\mathrm{q}^{\max }\left(\mathrm{mg} \cdot \mathrm{g}^{-1}\right)$ & $49.5 \pm 3.8$ & $55.4 \pm 4.7$ \\
$\mathrm{~K}$ & $0.60 \pm 0.15$ & $1.05 \pm 0.19$ \\
$1 / \mathrm{n}$ & $1.49 \pm 0.29$ & $1.04 \pm 0.23$ \\
$\mathrm{R}^{2}$ & 0.964 & 0.976 \\
$\mathrm{rss}$ & 47.724 & 34.138 \\
$\Delta \mathrm{H}^{\circ}\left(\mathrm{kJ} . \mathrm{mol}^{-1}\right)$ & \multicolumn{3}{|c}{36.200} \\
$\Delta \mathrm{S}^{\circ}\left(\mathrm{J} . \mathrm{mol}^{-1} \cdot \mathrm{K}^{-1}\right)$ & \multicolumn{2}{c}{116.070} \\
$\Delta \mathrm{G}^{\circ}\left(\mathrm{kJ} . \mathrm{mol}^{-1}\right)$ & -0.130 \\
\hline
\end{tabular}

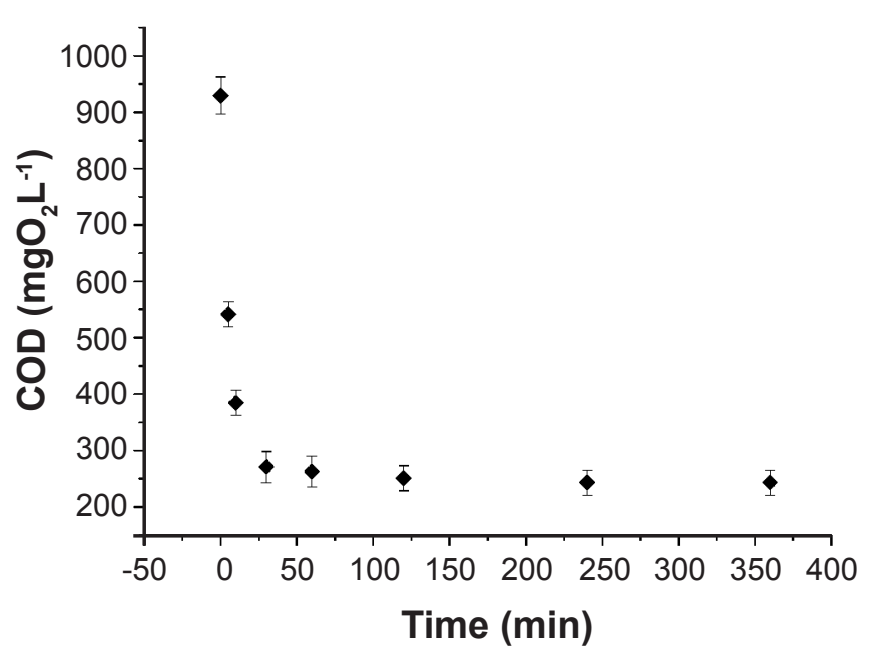

Figure 7: Real effluent COD removal by adsorption onto organoclay $\mathrm{A}\left(\mathrm{pH} \cong 4.5, \mathrm{~T} \cong 28 \pm 1^{\circ} \mathrm{C}\right)$.

process [13].

Typically, a textile effluent is composed of dyes, surfactants, dispersing agents, acids, and bases. After extensive research using a specific textile dye, an adsorptive study under the same conditions was carried out with a real effluent. However, as the real effluent is a mixture, three global parameters were evaluated: COD, color, and turbidity. The COD reduced from 929 to $243 \pm 31 \mathrm{mgO}_{2} \cdot \mathrm{L}^{-1}$, a reduction of $73.8 \pm 3.4 \%$, and this result is shown in Fig. 7; the color reduced from 1044 to $104 \pm 33$ Hazen, a reduction of $90.0 \% \pm 3.2 \%$; and the turbidity reduced from 516 to $83 \pm 7$ NTU, a reduction of $83.9 \% \pm 1.3 \%$. 


\section{CONCLUSIONS}

Given the results obtained in the removal of Nylosan blue B113 (NB) textile dye and real textile effluent by adsorption onto a regional clay, initially hydrophilic, but modified to organophilic, it is appropriate to suggest some considerations. The cation exchange capacity (CEC) analysis showed the presence of poly-cations in the interlayers of the natural clay, and the XRD analyses confirmed a satisfactory poly-cations exchange to hexadecyltrimethylammonium (HDTMA) cation, due to the increase of the interlayer distance, from 1.69 to $2.01 \mathrm{~nm}$. The BET analysis showed a decrease in the surface area, due to the presence of HDTMA cations in the interlayers of natural clay overlapping its surface. The $\mathrm{pH}$ of point of zero charge of the organoclay A was 7.03, favorable to adsorption in lower $\mathrm{pH}$ to anionic dyes, such as NB textile dye. The isotherm of Langmuir-Freundlich properly fitted the experimental data. Likewise, the pseudo-second order kinetic model showed satisfactory agreement between the experimental and predicted data. The thermodynamic results showed an adsorption mechanism governed by endothermic physisorption and a displacement of equilibrium in the adsorption direction after the temperature increase. Finally, the use of this organophilic material reduced chemical oxygen demand (COD), color, and turbidity from a real effluent, indicating that organoclays can be used as adsorbent materials in the industrial process.

\section{REFERENCES}

[1] J. Dasgupta, J. Sikder, S. Chakraborty, S. Curcio, E. Drioli, J. Environ. Manage. 147 (2015) 55.

[2] G. Wang, S. Wang, Z. Sun, S. Zheng, Y. Xi, Appl. Clay Sci. 148 (2017) 1.

[3] A.A. Adeyemo, I.O. Adeoye, O.S. Bello, Appl. Water Sci. 7 (2017) 543.

[4] A. Middea, L.S. Spinelli, F.G. Souza Jr, R. Neumann, T.L.A.P. Fernandes, O.F.M. Gomes, Appl. Clay Sci. 139 (2017) 45.

[5] A.Y.W. Sham, S.M. Notley, J. Environ. Chem. Eng. 6 (2018) 495.

[6] Z. Luo, M. Gao, Y. Ye, S. Yang, Appl. Surf. Sci. 324
(2015) 807.

[7] T. Ngulube, J.R. Gumbo, V. Masindi, A. Maity, J. Environ. Manage. 191 (2017) 35.

[8] H. Ali, Water Air Soil Pollut. 213 (2010) 251.

[9] Z. Huang, Y. Li, W. Chen, J. Shi, N. Zhang, X. Wang, Z.

Li, L. Gao, Y. Zhang, Mater. Chem. Phys. 202 (2017) 266.

[10] D.F. Brito, E.C. Silva Filho, M.G. Fonseca, M. Jaber, J. Environ. Chem. Eng. 6 (2018) 7080.

[11] S. Pandey, J. Mol. Liq. 241 (2017) 1091.

[12] A. Kausar, M. Iqbal, A. Javed, K. Aftab, Z. Nazli, H.N. Bhatti, S. Nouren, J. Mol. Liq. 256 (2018) 395.

[13] S. Gamoudi, E. Srasra, J. Mol. Struct. 1193 (2019) 522.

[14] K.J. Shah, S. Pan, A.D. Shukla, D.O. Shah, P. Chiang, J. Colloid Interface Sci. 529 (2018) 90.

[15] X. Ma, Y. Fan, X. Dong, R. Chen, H. Li, D. Sun, S. Yao, Minerals 8 (2018) 400.

[16] M. Ghadiri, W. Chrzanowski, R. Rohanizadeh, RSC Adv. 5 (2015) 29467.

[17] H. Ren, S. Tian, M. Zhu, Y. Zhao, K. Li, Q. Ma, S. Ding, J. Gao, Z. Miao, Appl. Clay Sci. 151 (2018) 29.

[18] T. Taguchi, Y. Kohno, M. Shibata, Y. Tomita, C. Fukuhara, Y. Maeda, J. Phys. Chem. Solids 116 (2018) 168.

[19] J.V.F.L. Cavalcanti, C.A.M. Abreu, O.S. Baraúna, M.A. Motta, Can. J. Chem. Eng. 92 (2014) 355.

[20] Y. Liu, L. Shen, Langmuir 24 (2008) 11625.

[21] T.S. Anirudhan, M. Ramachandran, Process Saf. Environ. Prot. 95 (2015) 215.

[22] I. Chaari, M. Feki, M. Medhioub, J. Bouzid, E. Fakhfakh, F. Jamoussi, J. Hazard. Mater. 172 (2009) 1623.

[23] R.P. Chicinas, H. Bedelean, R. Stefan, A. Măicăneanu, J. Mol. Struct. 1154 (2018) 187.

[24] M.V. Sperling, Introdução à qualidade das águas e ao tratamento de esgotos, Ed. UFMG, Belo Horizonte (2014) 83.

[25] T.J.M. Fraga, L.F.F. Silva, L.E.M.L. Ferreira, M.P. Silva, D.M.S.M. Fraga, C.M.B. Araújo, M.N. Carvalho, J.V.F.L. Cavalcanti, M.G. Ghislandi, M.A. Motta, Environ. Sci. Pollut. Res. 27 (2020) 9718.

[26] T.S. Pessôa, L.E.L. Ferreira, M.P. Silva, L.M.P. Neto, B.F. Nascimento, T.J.M. Fraga, E.F. Jaguaribe, J.V.F.L. Cavalcanti, M.A. Motta, J. Clean. Prod. 240 (2019) 118047. (Rec. 14/09/2020, Rev. 25/01/2021, Ac. 12/02/2021) 